\title{
Pemberdayaan Karyawan Dalam Penerapan Keselamatan dan Kesehatan Kerja Berbasis Fault Tree Analysis
}

\author{
Muhammad Yusuf $^{1 *}$, Titin Isna Oesman ${ }^{2}$, dan Nugroho Adi Wicaksono ${ }^{3}$ \\ 1,2,3) Jurusan Teknik Industri, Institut Sains \& Teknologi AKPRIND, Yogyakarta \\ ${ }^{*}$ e-mail korespondensi: yusuf@akprind.ac.id \\ doi: https://doi.org/10.24843/JEI.2020.v06.i01.p07 \\ Article Received: 11 Juni 2020; Accepted: 29 Juni 2020; Published: 30 Juni 2020
}

\begin{abstract}
Abstrak
Perusahaan WL Aluminium merupakan sebuah usaha kecil menengah yang bergerak di bidang produksi kebutuhan rumah tangga serta belum ada unit yang mengelola sistem manajemen kesehatan dan keselamatan kerja (K3). Sementara karyawan belum dilibatkan dalam upaya menerapkan K3. Penelitian ini bertujuan untuk mengetahui sistem pengelolaan manajemen K3, bahaya kecelakaan kerja dan faktor penyebab kecelakaan kerja yang terjadi di perusahaan WL Aluminium. Metode yang digunakan adalah pendekatan Fault Tree Analysis (FTA) dengan melibatkan karyawan berdasarkan Hazard Identification Risk Assessment (HIRA) dan analisis SWOT. Hasil penelitian dapat diketahui pada metode HIRA terdapat 3 jenis kegiatan produksi yang memiliki nilai risk rating number (RRN) cukup tinggi. Penyebab utama kecelakaan kerja dengan metode FTA adalah potensi kecelakaan kerja yang terjadi yaitu jari tangan terkena bahan baku aluminium, tangan terkena wadah pencetakan yang masih panas, sakit pada lengan tangan, jari tangan terkena mata bubut dan sakit pada punggung. Untuk matriks SWOT, cara yang digunakan pihak perusahaan untuk dapat mencapai pertumbuhan yang baik antara lain dengan melibatkan karyawan melalui upaya membuat tim $\mathrm{K} 3$ untuk pemantauan dan evaluasi terhadap pelaksanaan program K3, membuat sistem administrasi yang bertujuan untuk pengelolaan sistem manajemen K3, serta sosialisi mengenai K3. Dengan pemberdayaan karyawan dalam manajemen $\mathrm{K} 3$ diharapkan zero accident nantinya dapat tercapai
\end{abstract}

Kata kunci: keselamatan dan kesehatan kerja, Fault Tree Analysis, pemberdayaan

\section{Employee Empowerment in the Implementation of Occupational Heath and Safety Based on Fault Tree Analysis}

\begin{abstract}
WL Aluminium industry is a small and medium enterprises which is engaged in the production of household needs and there is no unit that manages the Occupational Health and Safety (OHS). Meanwhile the employee were not encouraged in OHS implementation. This study aims to determine the management system of occupational health and safety management, the dangers of work accidents and the factors causing occupational accidents that occur in the WL Aluminium company. The methods used are Fault Tree Analysis (FTA) approaches that encourage the employee based on Hazard Identification Risk Assessment (HIRA) and SWOT analysis. The results of the research can be seen in the HIRA method there are 3 (three) production activities that have a high enough risk rating number $(R R N)$. The main cause of work accidents with the FTA method is the potential for workplace accidents that occur, namely the fingers are exposed to aluminium raw materials, the hands are exposed to hot printing containers, pain in the arms, fingers are affected by lathe eyes and back pain. For the SWOT matrix strategy, the methods used by the company to achieve good growth include employee participation through creating an OHS team for monitoring and evaluating the implementation of the
\end{abstract}


OHS program, creating an administrative system aimed at managing the OHS management system, as well as socializing about OHS, empowerment of the employee in OHS implementation and the goal of zero accident can be achieved.

Keywords: oocupational health and safety, Fault Tree Analysis, empowerment

\section{PENDAHULUAN}

Perusahaan WL Aluminium merupakan perusahaan industri kecil dan bergerak di bidang produksi peralatan rumah tangga yang berasal dari aluminium antara lain: panci, ketel, wajan, panci tutup kaca. Jangkauan pemasaran meliputi kota Yogyakarta, Jawa Tengah, Jawa Timur. Berdasarkan pengamatan awal yang dilakukan yaitu terdapat temuan-temuan potensi bahaya kecelakaan kerja seperti terkena lelehan hasil peleburan, debu sisa pengikiran, terkena goresan pencetakan yang terjadi di bagian produksi proses peleburan, pencetakan, pengikiran, pembubutan. Masalah yang terdapat di WL Aluminium tersebut perlu dilakukan evaluasi dan analisis pada bagian ruang produksi terutama pada kesehatan dan keselamatan pekerja.

Agar terhindar dari kecelakaan akibat kerja, perlu dilakukan analisis dengan melibatkan karyawan. Oleh karena itu diperlukan metode analisis yang mudah diterapkan. Metode Fault Tree Analysis (FTA) merupakan suatu alat untuk menganalisis, dengan tampilan visual dan mengevaluasi jalur dari suatu kegagalan pada sistem serta menyediakan suatu mekanisme untuk mengevaluasi tingkatan bahaya pada sistem (Anthony, 2015). FTA merupakan sebuah analytical tool yang menerjemahkan secara grafik kombinasi-kombinasi dari kesalahan yang menyebabkan kegagalan dari sistem, berguna mendeskripsikan dan menilai kejadian di dalam sistem (Foster, 2004).

Untuk melakukan analisis FTA, sebelumnya dilakukan analisis SWOT merupakan instrumen perencanaan strategi yang klasik sebagai cara sederhana memperkirakan cara terbaik melaksanakan suatu strategi (Stevanus, 2015), sedangkan HIRA merupakan suatu proses mengidentifikasi bahaya, mengukur, mengevaluasi, risiko yang muncul dari sebuah bahaya, kemudian menghitung kecukupan dari tindakan pengendalian dan memutuskan apakah risiko yang ada dapat diterima atau tidak (Helmidadang, 2012).

Berdasarkan uraian di atas, maka analisis FTA dapat dilaksanakan dengan dilengkapi analisis SWOT dan identifikasi faktor risiko menggunakan HIRA sehingga dapat menilai nmanajemen keselamatan dan kesehatan kerja (K3). Dalam hal ini pemahaman setiap komponen karyawan dalam menerapkan FTA bersma XSWOT dan HIRA merupakan hal penting untuk menghasilkan kajian yang terbaik.

\section{METODE}

Penelitian ini merupakan penelitian non eksperimen observasional terhadap manajemen K3 pada pekerja di bagian proses produksi. Evaluasi dilakukan dengan pendekatan FTA, SWOT dan HIRA. Observasi dilaksanakan pada bulan Januari-Maret 2019. Data yang dikumpulkan antara lain organisasi K3, potensi bahaya kecelakaan kerja dan evaluasi faktor tertinggi penyebab potensi bahaya yang ditimbulkan. Setelah diketahui kondisi tingkat kecelakaan kerja kemudian dilakukan analisis SWOT untuk didapatkan kekuatan, kelemahan, peluang dan ancaman kesehatan dan keselamatan kerja para pekerja WL Aluminium. Berdasarkan pengolahan data matriks SWOT penentuan dan penerapan kesehatan dan keselamatan bekerja pada WL Aluminium terdapat lebih banyak di kelemahan dibandingkan dengan kekuatan, peluang, dan ancaman.

Peralatan serta bahan yang digunakan dalam penelitian ini antara lain kuesioner, alat tulis untuk melakukan pencatatan dan pendataan, kamera digital untuk mengambil gambar kerja, 
papan landasan untuk menulis, lembar kerja SWOT, Hazard Identification Risk Assessment (HIRA) dan Fault Tree Analysis (FTA).

\section{HASIL DAN PEMBAHASAN}

Kondisi tingkat kecelakaan kerja di bagian produksi yang diukur selama periode Januari sampai Maret 2019, berdasarkan Tingkat Kekerapan Kecelakaan Kerja (Frequency Rate), Tingkat Keparahan Kecelakaan Kerja (Severity Rate) dan Nilai T Selamat (Safe-T-Score) diperoleh data seperti pada Tabel 1.

Tabel 1

Kondisi Kecelakaan Kerja Bagian Produksi

Periode Januari - Maret 2019

\begin{tabular}{cccc}
\hline No & Indikator & $\begin{array}{c}\text { Skor per 192.000 } \\
\text { jam kerja/orang }\end{array}$ & Ket \\
\hline 1. & Tingkat kekerapan kecelakaan kerja & 1 & 0 \\
2. & Tingkat keparahan kecelakaan kerja & 11 & 0 \\
3. & Nilai T Selamat & 0 & -2 \\
\hline
\end{tabular}

Berdasarkan Tabel 1, nampak bahwa tingkat kekerapan kecelakaan kerja (Frequency Rate) diperkirakan 1 per 192.000 jam kerja orang dari seharusnya tidak ada kekerapan kecelakaan kerja. Sementara tingkat keparahan kecelakaan kerja (Severity Rate) pada bulan Januari-Maret 2019 menunjukkan sebanyak 11 hari hilang per 192.000 jam kerja orang akibat kecelakaan kerja, sehingga hal ini mengurangi waktu kerja karyawan. Kemudian Nilai T Selamat (Safe - T - Score) pada bulan Januari - Maret 2019 adalah 0 (nol) masih dibatas ambang batasan dengan nilai -2 (minus dua) yaitu tidak bermakna dan masih dalam tahap wajar.

Berdasarkan kondisi kecelakaan kerja yang terjadi yaitu 1/192.000 jam kerja orang dan 11 hari hilang/192.000 jam kerja orang, maka ditelusuri pelaksanaan K3 di perusahaan. Pelaksanaan K3 dicatat dengan menggunakan kuesioner. Untuk perhitungan persentase pernyataan responden yang merupakan pekerja bagian produksi mengenai program pelaksaan mengenai K3 dicatat berdasarkan 7 pertanyaan aspek komunikasi dan pelatihan, 5 pertanyaan aspek lingkungan kerja dan kesehatan, dan 8 pertanyaan aspek kecelakaan dan sakit akibat kerja seperti dijelaskan pada Tabel 2.

Tabel 2

Pendapat Responden terhadap Pelaksanaan K3

\begin{tabular}{cccc}
\hline \multirow{2}{*}{ No } & Aspek & \multicolumn{2}{c}{ Jumlah Responden } \\
\cline { 3 - 4 } & Ka $(\%)$ & Tidak (\%) \\
\hline 1. & Komunikasi dan Pelatihan & $179(85)$ & $31(15)$ \\
2. & Lingkungan Kerja dan Kesehatan & $108(72)$ & $42(28)$ \\
3. & Kecelakaan dan Sakit Akibat Kerja & $187(77)$ & $53(23)$ \\
\hline
\end{tabular}

Berdasarkan Tabel 2, nampak sebagian besar sudah diberi pembinaan K3 oleh perusahaan (85\%), untuk lingkungan kerja dan kesehatan responden cukup baik $(72 \%)$ dan sebagian besar sudah menggunakan alat pelindung diri (APD). Berdasarkan kusioner yang telah dikumpulkan datanya tersebut, sebenarnya pembinaan K3 sudah dilaksanakan termasuk pemberian APD dan penataan lingkungan kerja di bagian produksi. Namun masih ada responden yang menyatakan belum ada pembinaan (15\%), lingkungan kerja dan Kesehatan 
masih belum baik (28\%) dan masih belum menggunakan APD (23\%). Artinya, kondisi ini memerlukan manajemen K3 lebih intensif dengan melibatkan karyawan secara keseluruhan.

Untuk menilai risiko proses produksi terkait identifikasi kecelakaan kerja, dilakukan perhitungan Risk Rating Number (RRN) dengan mempergunakan HIRA. Identifikasi kecelakaan kerja dengan penilaian risiko sebagai salah satu poin penting untuk mengimplementasikan sistem manajemen keselamatan dan kesehatan kerja (Roehan, dkk., 2014.). Hasil penilaian risiko bahaya bisa dilihat pada Tabel 3.

Tabel 3

Penilaian Risiko Bahaya

\begin{tabular}{clccc}
\hline No & Jenis Kegiatan & $\begin{array}{c}\text { Severity } \\
\text { Score }\end{array}$ & $\begin{array}{c}\text { Frekuensi } \\
\text { Score }\end{array}$ & $\begin{array}{c}\text { Risk Rating } \\
\text { Number (RRN) }\end{array}$ \\
\hline 1 & Peleburan & 3 & 3 & 9 \\
2 & Pencetakan & 3 & 3 & 9 \\
3 & Pengikiran & 2 & 3 & 6 \\
4 & Pembubutan & 3 & 3 & 9 \\
5 & Pelabelan Merk & 2 & 2 & 4 \\
\hline
\end{tabular}

Berdasarkan Tabel 3, maka bagian peleburan, percetakan dan pembubutan memiliki RRN 9, sehingga termasuk risiko menengah, sementara bagian pengikiran memiliki RRN 6 juga termasuk risiko menengah. Hanya bagian pelabelan merk yang memiliki risiko rendah dengan RRN 4 (Roehan, dkk., 2014). Ini menunjukkan ada 3 bagian proses produksi yang memiliki risiko tinggi yaitu peleburan, pencetakan dan pembubutan. Hal ini sesuai dengan hasil identifikasi dan penilaian risiko menurut HIRA seperti tersaji pada Tabel 4.

Tabel 4

Hazard Identification and Risk Assessment Pada Proses Produksi

\begin{tabular}{|c|c|c|c|c|c|c|c|c|c|}
\hline \multirow{2}{*}{$\begin{array}{l}\mathrm{N} \\
\mathrm{o}\end{array}$} & \multirow{2}{*}{$\begin{array}{c}\text { Jenis } \\
\text { Kegiatan }\end{array}$} & \multirow{2}{*}{ Potensi Bahaya } & \multicolumn{2}{|c|}{ Severity } & \multicolumn{2}{|c|}{ Frekuensi } & \multirow{2}{*}{$\begin{array}{l}\text { Indek } \\
\text { Risiko } \\
\text { Bahaya }\end{array}$} & \multirow{2}{*}{$\begin{array}{c}\mathrm{RR} \\
\mathrm{N}\end{array}$} & \multirow{2}{*}{$\begin{array}{c}\text { Prioritas } \\
\text { Risiko }\end{array}$} \\
\hline & & & Category & Score & Level & Score & & & \\
\hline 1 & Peleburan & $\begin{array}{l}\text { Jari tangan } \\
\text { terkena bahan } \\
\text { baku } \\
\text { aluminium saat } \\
\text { ingin } \\
\text { meleburkan ke } \\
\text { tungku }\end{array}$ & III & 3 & $\mathrm{C}$ & 3 & $3 \mathrm{C}$ & 9 & $\begin{array}{c}\text { Prioritas } \\
\text { Menengah }\end{array}$ \\
\hline 2 & Pencetakan & $\begin{array}{l}\text { Tangan terkena } \\
\text { wadah } \\
\text { pencetakan } \\
\text { yang masih } \\
\text { panas }\end{array}$ & III & 3 & $\mathrm{C}$ & 3 & $3 \mathrm{C}$ & 9 & $\begin{array}{l}\text { Prioritas } \\
\text { Menengah }\end{array}$ \\
\hline 3 & Pengikiran & $\begin{array}{l}\text { Sakit pada } \\
\text { lengan tangan }\end{array}$ & IV & 2 & $\mathrm{C}$ & 3 & $4 \mathrm{C}$ & 6 & $\begin{array}{c}\text { Prioritas } \\
\text { Menengah }\end{array}$ \\
\hline 4 & $\begin{array}{l}\text { Pembubuta } \\
\mathrm{n}\end{array}$ & $\begin{array}{l}\text { Jari tangan } \\
\text { terkena mata } \\
\text { bubut }\end{array}$ & III & 3 & $\mathrm{C}$ & 3 & $3 \mathrm{C}$ & 9 & $\begin{array}{c}\text { Prioritas } \\
\text { Menengah }\end{array}$ \\
\hline 5 & $\begin{array}{l}\text { Pelabelan } \\
\text { Merk }\end{array}$ & $\begin{array}{l}\text { Sakit pada } \\
\text { punggung }\end{array}$ & IV & 2 & $\mathrm{D}$ & 2 & 4D & 4 & $\begin{array}{l}\text { Prioritas } \\
\text { Rendah }\end{array}$ \\
\hline
\end{tabular}


Berdasarkan Tabel 2 nampak bahwa di ketiga bagian produksi tersebut terjadi kecelakaan kerja yaitu jari tangan terkena bahan baku aluminium saat ingin meleburkan ke tungku, tangan terkena wadah pencetakan yang masih panas dan jari tangan terkena mata bubut. Indeks Risiko Bahaya menunjukkan bahwa kecelakaan itu sesuai dengan indeks risiko bahaya yang dijumpai tinggi di bagian peleburan, pencetakan dan pembubutan yaitu angka indek $3 \mathrm{C}$ sehingga kriterianya termasuk tidak diinginkan dan memerlukan aktivitas manajemen. Sementara itu bagian pengikiran ada di $4 \mathrm{C}$ dan bagian pelabelan merk ada di 4D, termasuk dapat diterima tanpa peninjauan (Roehan, dkk., 2014).

Berdasarkan angka indek risiko bahaya, menunjukkan perlunya ada aktivitas manajemen dalam melaksanakan K3. Namun peran serta karyawan juga sangat penting, karena pelaksanaan K3 memerlukan partisipasi dari semua pihak dalam proses produksi tersebut. Untuk memahami kondisi yang ada di perusahaan, maka dilakukan analisis SWOT meliputi kekuatan, kelemahan, peluang dan tantangan atau ancaman (Tarwaka, 2017). Hasil analisis SWOT dapat dipergunakan untuk menyusun strategi pelaksanaan K3 pada semua komponen dari SWOT. Hasil analisis dan strategi mengatasinya disajikan pada Tabel 5.

Hasil analisis SWOT menunjukkan bahwa kelemahan pelaksanaan K3 terjadi karena tidak ada tim manajemen K3 pada WL Aluminium. Hal ini menyebabkan tidak ada administrasi yang mencatat mengenai kecelakaan saat kerja. Sementara tingkat pendidikan SDM pekerja yang masih rendah dan pengetahuan pekerja tentang K3 belum memadai, sehingga memerlukan tindakan segera dalam mensosialisasikan K3. Selain itu penerapan sanksi bagi pelanggar juga penting dijadikan salah satu bahan pertimbangan untuk meningkatkan partisipasi dan sekaligus memberdayakan karyawan dalam manajemen K3. Memperhatikan hasil analisis SWOT tersebut, maka strategi yang harus dilakukan adalah memperbaiki kelemahan yang ada, serta mempertahankan kekuatan yang sudah dimiliki.

Tabel 5

Analisis SWOT Perusahaan terkait manajemen K3

\begin{tabular}{|c|c|c|}
\hline 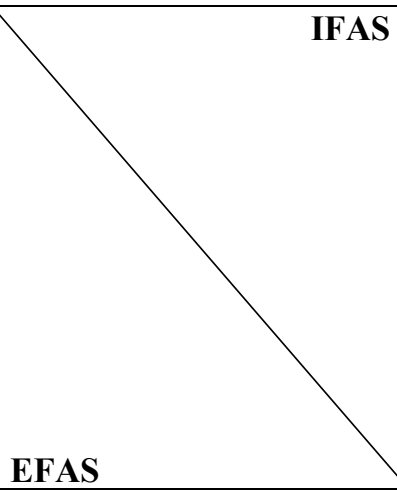 & $\begin{array}{l}\text { STRENGTH (S) : } \\
\text { 1. WL Aluminium menyediakan } \\
\text { alat pelindung diri (APD) } \\
\text { 2. WL Aluminium memiliki } \\
\text { SOP pada perusahaan } \\
\text { 3. WL Aluminium melakukan } \\
\text { sosialisasi sebelum kerja } \\
\text { mengenai APD }\end{array}$ & $\begin{array}{l}\text { WEAKNESS (W): } \\
\text { 1. Tidak ada tim manajemen K3 pada WL } \\
\text { Aluminium } \\
\text { 2. Tidak ada administrasi yang mencatat } \\
\text { mengenai kecelakaan saat kerja } \\
\text { 3. Tingkat pendidikan SDM pekerja yang } \\
\text { masih rendah } \\
\text { 4. Pengetahuan pekerja tentang K3 belum } \\
\text { memadai } \\
\text { 5. Tidak ada sanksi yang diberikan kepada } \\
\text { pekerja yang tidak menggunakan APD, } \\
\text { hanya berupa teguran }\end{array}$ \\
\hline & $\begin{array}{l}\text { STRATEGI (SO): } \\
\text { 1. Membuat tim kerja yang } \\
\text { mengelola sistem manajemen } \\
\text { K3 } \\
\text { 2. Memberikan pelatihan- } \\
\text { pelatihan K3 pada pekerja } \\
\text { WL Aluminium } \\
\text { 3. Memberikan panduan SOP } \\
\text { terhadap pekerja yang baru } \\
\text { (training) } \\
\text { 4. Melakukan perbaikan dan } \\
\text { pengembangan serta } \\
\text { pemantauan terhadap } \\
\text { pelaksanaan prosedur- } \\
\text { prosedur K3 }\end{array}$ & $\begin{array}{l}\text { STRATEGI (WO): } \\
\text { 1. Membuat tim manajemen K3 untuk } \\
\text { pemantauan dan evaluasi terhadap } \\
\text { pelaksanaan program K3 } \\
\text { 2. Membuat sistem administrasi yang } \\
\text { bertujuan untuk pengelolaan } \\
\text { manajemen K3 } \\
\text { 3. Melakukan sosialisi mengenai K3 } \\
\text { 4. Melakukan pemantauan dan evaluasi } \\
\text { terhadap pelaksanaan program K3 } \\
\text { 5. Memberikan sanksi pada pekerja yang } \\
\text { tidak menggunakan APD }\end{array}$ \\
\hline
\end{tabular}




\section{OPPORTUNITY (O):}

1. Menciptakan tim manajemen K3 untuk memantau dan mengevaluasi terhadap pelaksanaan program K3

2. Memberikan pelatihan K3 terhadap pekerja WL Aluminium

3. Perusahaan akan memberikan sanksi pada pekerja saat sudah terbentuk tim $\mathrm{K} 3$

\section{THREAT (T):}

1. Biaya pengeluaran akibat kecelakaan kerja bertambah

2. Pekerja mengalami kecelakaan kerja

\section{STRATEGI (SO):}

1. Membuat tim kerja yang mengelola sistem manajemen K3

2. Memberikan pelatihanpelatihan $\mathrm{K} 3$ pada pekerja WL Aluminium

3. Memberikan panduan SOP terhadap pekerja yang baru (training)

4. Melakukan perbaikan dan pengembangan serta pemantauan terhadap pelaksanaan prosedurprosedur K3

\section{STRATEGI (ST):}

1. Meningkatkan pengetahuan pekerja tentang K3

2. Memberikan pelatihanpelatihan mengenai $\mathrm{K} 3$ pada pekerja

3. Memberikan APD yang sesuai dengan kebutuhan pekerja

4. Meningkatkan kesadaran pekerja akan bahaya dan risiko kecelakaan kerja

\section{STRATEGI (WO):}

1. Membuat tim manajemen $\mathrm{K} 3$ untuk pemantauan dan evaluasi terhadap pelaksanaan program $\mathrm{K} 3$

2. Membuat sistem administrasi yang bertujuan untuk pengelolaan sistem manajemen K3

3. Melakukan sosialisi mengenai K3

4. Melakukan pemantauan dan evaluasi terhadap pelaksanaan program K3

5. Memberikan sanksi pada pekerja yang tidak menggunakan APD

\section{SRATEGI (WT):}

1. Membuat tim K3 untuk memberikan pelatihan - pelatihan mengenai $\mathrm{K} 3$ pada pekerja

2. Memfasilitasi pekerja dengan alat pelindung diri (APD) yang sesuai dengan kebutuhan pekerja

3. Memberikan sanksi terhadap pekerja yang tidak menggunakan alat pelindung diri (APD)

FTA merupakan suatu model metode bagan untuk mendisplai dan mengidentifikasi antara berbagai kombinasi kegagalan peralatan dan kesalahan manusia yang dilakukan secara logis (Tarwaka, 2016). Berdasarkan identifikasi HIRA dan analisis SWOT, maka penerapan FTA dapat dilakukan untuk menilai sumber dan potensi terjadinya kecelakaan kerja pada bagian produksi tersebut. Model analisis FTA dapat dilakukan terhadap setiap kejadian kecelakaan kerja. Model analisis FTA dapat digambarkan seperti pada Gambar 1.

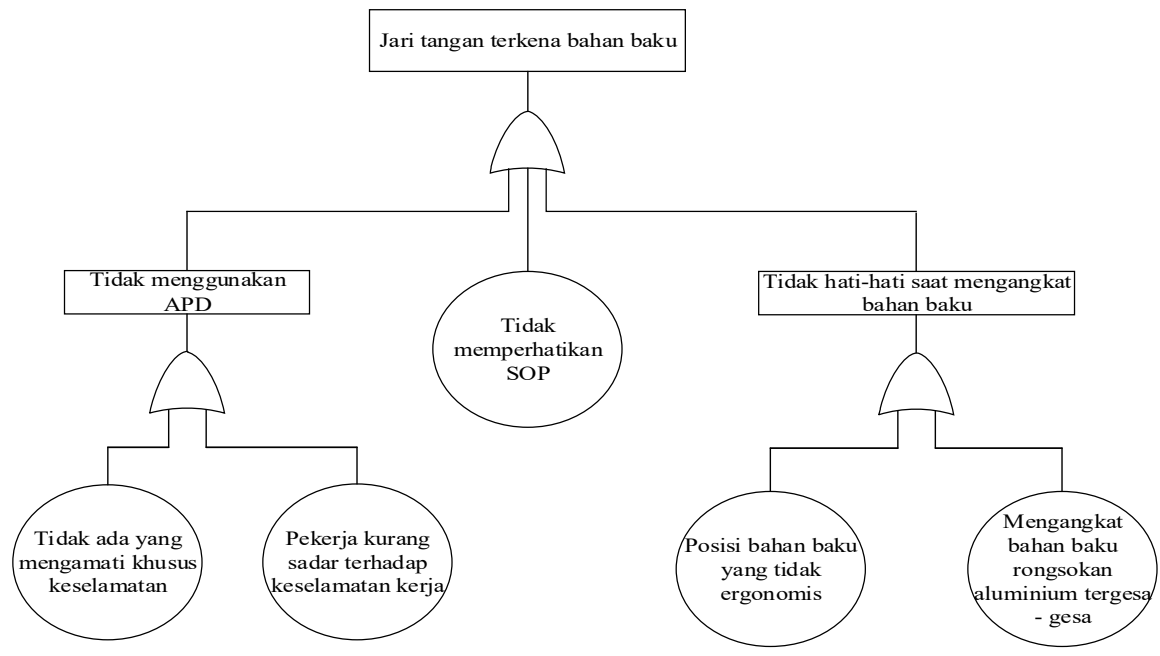

Gambar 1 Model FTA pada Jari Tangan Terkena Bahan Baku

Gambar 1, merupakan model analisis FTA pada kasus jari tangan terkena bahan baku, dengan memperhatikan sumber kecelakaan yaitu tidak menggunakan APD dan tidak hati-hati saat mengangkat bahan baku. Ini menunjukkan sumbernya pada tenaga kerja yang tidak mengikuti 
SOP dan tidak menyadari pentingnya keselamatan kerja. Gambar 2 model analisis FTA tangan terkena wadah pencetakan yang panas,

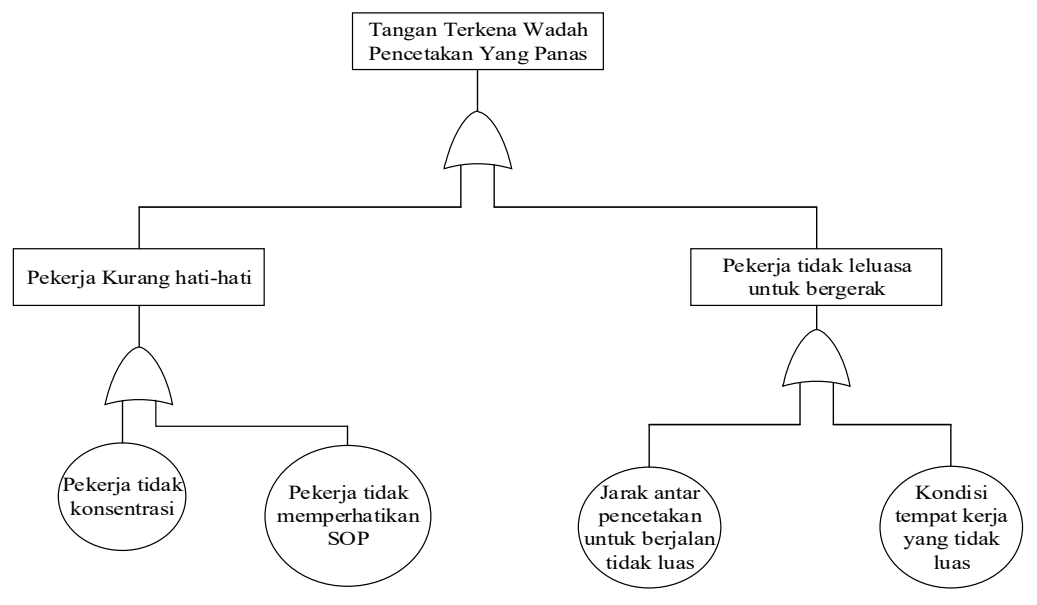

Gambar 2 Model FTA pada Tangan Terkena Wadah Pencetakan Yang Panas

Gambar 2 juga menunjukkan peran pekerja dalam kecelakaan yang terjadi yaitu tidak hati-hati saat bekerja. Hal ini disebabkan tidak konsentrasi dan tidak mengindahkan SOP. Selanjutnya pada Gambar 3 memperlihatkan analisis FTA pada jari tangan terkena mata bubut.

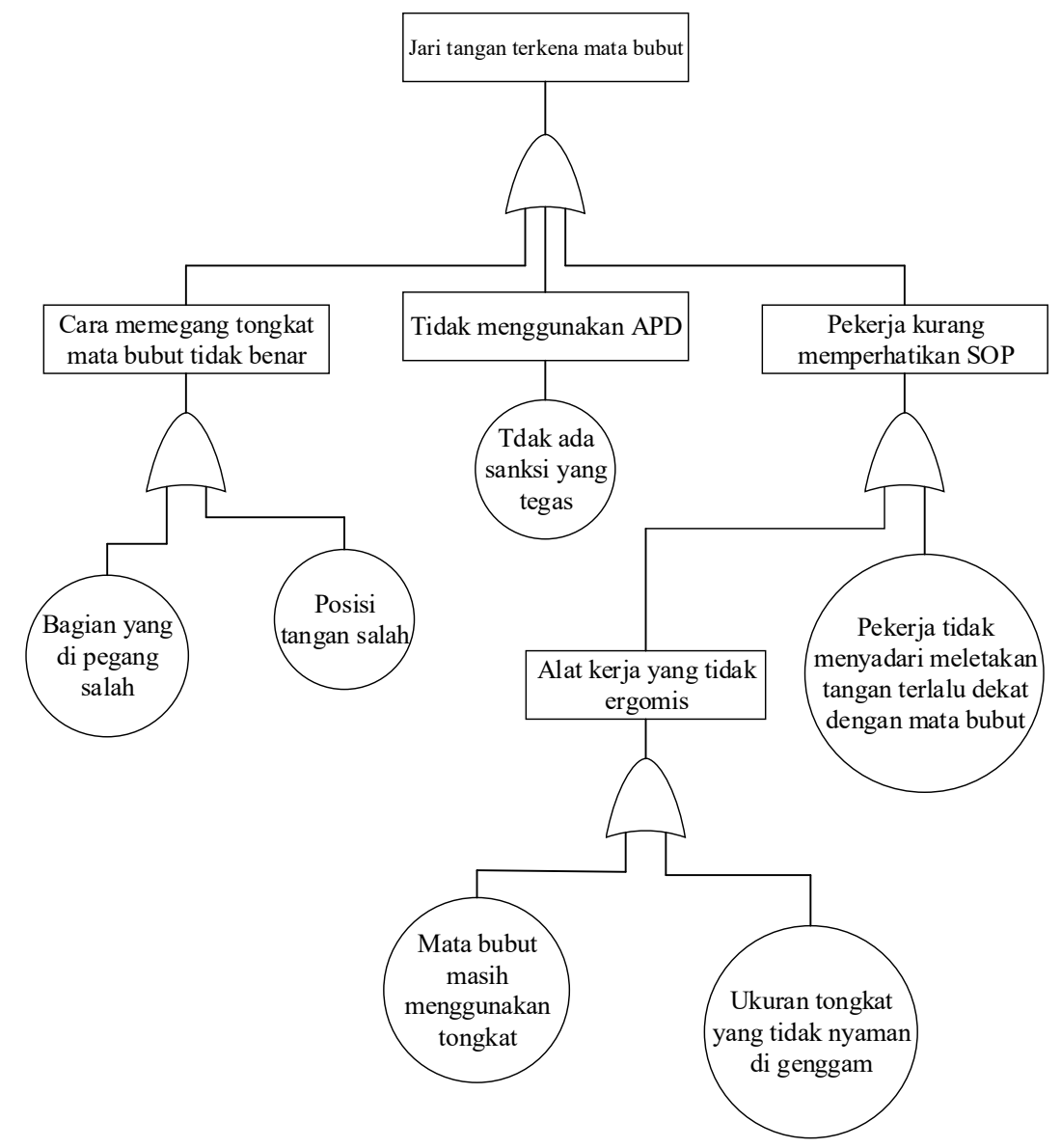

Gambar 3. Model FTA pada Jari Tangan Terkena Mata Bubut 
Gambar 3 juga menunjukkan sumber kecelakaan kerja bersumber dari pekerja yang tidak memperhatikan SOP sehingga tidak bisa memegang tongkat dengan benar dan tidak menggunakan APD.

Berdasarkan analisis FTA didapatkan pada bagian peleburan, pencetakan dan pembubutan merupakan bagian produksi dengan memiliki risiko tinggi. Hal ini disebabkan oleh berbagai faktor seperti tidak ada yang mengamati khusus keselamatan, pekerja kurang sadar terhadap keselamatan kerja, tidak memperhatikan standar pengerjaan, posisi bahan baku tidak ergonomis, pada pencetakan yaitu pekerja tidak konsentrasi, jarak antar pencetakan untuk jalan tidak luas, kondisi tempat kerja yang tidak luas, pada pengikiran yaitu alat pengikir masih manual, alat pengikir tidak ergonomis, pergerakan tangan saat mengikir salah, pada pembubutan yaitu, bagian yang di pegang salah, posisi tangan salah, mata bubut masih menggunakan tongkat.

Dari analisis tersebut menunjukkan tidak adanya manajemen K3 yang secara khusus mengawasi, mencatat dan memberikan edukasi kepada karyawan. Keterlibatan karyawan juga belum bisa dilakukan, karena hal ini sesuai dengan kondisi perusahaan yang belum memiliki manajemen K3. Sementara itu, keterlibatan karyawan menjadi kurang mendapatkan edukasi secara berkelanjutan. Dengan demikian pemberdayaan karyawan diperlukan untuk bisa secara mandiri melaksanakan K3 minimal dari diri sendiri maupun lingkungan kerja dan kondisi kerja masing-masing.

\section{SIMPULAN}

Berdasarkan analisis FTA bersama analisis SWOT dan identifikasi mengunakan HIRA dapat disimpulkan bahwa penerapan $\mathrm{K} 3$ di perusahaan sudah tersedia ditandai adanya alat pelindung diri, panduan SOP, tetapi belum terdapat tim manajemen K3 untuk mengevaluasi sehingga masih terjadi suatu insiden kecelakaan kerja. Dalam hal ini keterlibatan karyawan belum dilakukan, sehingga pemberdayan karyawan dalam manajemen K3 belum ada.

Identifikasi potensi kecelakaan kerja di perusahaan pada tingkat kekerapan terjadi 1 (satu) kali terjadi kecelakaan kerja pada bulan Januari - Maret 2019, tingkat keparahan kecelakaan kerja 11 hari hilang, dan untuk nilai T selamat -2 (minus dua) masih dibatas ambang batas dan masih dalam tahap wajar.

Potensi kecelakaan kerja yang terjadi yaitu jari tangan terkena bahan baku aluminium, tangan terkena wadah pencetakan yang masih panas, sakit pada lengan tangan, jari tangan terkena mata bubut, sakit pada punggung terutama terjadi di bagian peleburan, pencetakan dan pembubutan.

Adanya penelitian ini diharapkan kedepan penerapan K3 pada perusahaan menjadi zero accident.

\section{DAFTAR PUSTAKA}

Anthony, R. 2015. The Applicationof Hazard Identification and Risk Analysis (HIRA) And Fault Tree Analysis (FTA) Methods For Controlling Occupational Accidents in Mixing Division Dewi-Dewi Farm. Jurnal Ilmiah Teknik Industri, Vol. 3(2).

Foster, S. T. 2004. Managing Quality: an Integrative Aooroahc, Pearson Education International.

Helmidadang, 2012. Hazard Identification Risk Assessment (HIRA). Available from http://helmidadang.wordpress.com/2012/12/30/hira-hazard-identification-and-riskAssessment-and-sample-of-hira/. Akses 19 Mei 2013.

Roehan, K., Rizki, A. 2014. Usulan Perbaikan Sistem Manajemen Keselamatan dan Kesehatan Kerja (SMK3). Jurnal Online Institut Teknologi Nasional, Vol. 02(02). 
Stevanus, S. 2015. Aplikasi Metode Analisis Swot Untuk Merumuskan Strategi Bersaing Pada PT. Berkat Karya Lestari. Jurnal Manajemen Bisnis, Vol. 03(02).

Tarwaka, 2016. Dasar-dasar Keselamatan Kerja Serta Pencegahan Kecelakaan di Tempat Kerja. Surakarta.

Tarwaka, 2017. Keselamatan, Kesehatan Kerja dan Ergonomi (K3E) Dalam Perspektif Bisnis. Surakarta. 